UDC 372.881.111.1

DOI https://doi.org/10.24919/2308-4863/42-3-10

Carmen CHIREA-UNGUREANU, orcid.org/0000-0002-7345-552X

Doctor of Philosophy,

Associate Professor at the Fundamental Sciences and Humanities Department

Constanta Maritime University

(Constanta, Romania) carmen_chirea@hotmail.com

\title{
"MARINISATION" OF MARITIME ENGLISH (ME) TEACHERS: THE MUST-HAVE IN MARITIME EDUCATION AND TRAINING (MET)
}

Education is a complex world with many styles, values, and philosophies. When choosing what is proper for us, it is essential to consider what system fits our learning methods. Multidisciplinary learning is a beautiful way to integrate our education into a complete unit rather than trying to draw connections between seemingly unrelated parts. The benefits of an interdisciplinary approach in education are abundant! The techniques, methods, and skills taught in the English language can be transferred to other content areas in all respects. That is the reason why researchers said that they are "portable" (Perkins, 1986). In Maritime Education and Training (MET) institutions, multidisciplinary teaching supports and promotes this transfer. Interdisciplinary skills made an argument among teaching specialists: "do cross-functional skills exist in themselves, can they be identified and established, can a frame of reference be drawn up as in the case of an occupation, or is it a general potential that can be expressed in different circumstances?" (Parcon, 2006). Students can find the essential information in core subject areas, but, at the same time, they are not learning how to apply their knowledge effectively in thinking and reasoning (Applebee, Langer, Mullis, 1989). Therefore, strategies for monitoring comprehension can direct to reading material in any content area. Cause-and-effect relationships exist in interdisciplinary studies. Multidisciplinary learning is not our average school experience. The multidisciplinary curriculum is one in which a single topic comes from the viewpoint of more than one discipline. Accordingly, it is closely associated with thematic teaching and synergistic teaching (or "combined interaction"). The MET institutions see the advantages of multidisciplinary education and strive to integrate it into their education platform. This paper explores Maritime English (ME) symbiotic teacher-student relationships to cultivate multidisciplinary teaching to provide the conditions under which effective learning environments occur. This comprehensive approach to education requires the close collaboration of multiple teachers to create this integrated, enhanced learning experience for students across various disciplines. Students learn more when using the ME skills to analyze what they were taught, record everything they were taught, and communicate with their classmates, professors, and maritime industry members.

Key words: multidisciplinary teaching, interdisciplinary skills, Maritime English skills, symbiotic teacher-student relationships.

Кармен КІРЕА-УНГУРЕАНУ, orcid.org/0000-0002-7345-552X, доктор філософіï, доцент кафедри фундаментальних та гуманітарних дисииплін

Констанцького морського університету (Констаниа, Румунія) carmen_chirea@hotmail.com

\section{МУЛЬТИДИСЦИПЛІНАРНЕ НАВЧАННЯ: НЕОБХІДНІСТЬ У СИСТЕМІ МОРСЬКОЇ ОСВІТИ ТА ПІДГОТОВКИ}

\begin{abstract}
Освіта - иее складний світ із багатьма стилями, цінностями та філософією. Обираючи те, щуо підходить нам, важливо враховувати, яка система відповідає нашим методам навчання. Мультидисциплінарне навчання - иее чудовий спосіб інтегрувати нашу освіту в цілісну одиницю, а не намагатися встановити зв 'язки між, здавалося б, не пов'язаними між собою частинами. Переваги міждисциплінарного підходу в освіті величезні! Методи, прийоми та вміння, здобуті під час вивчення англійської мови, можна перенести в інші сфери діяльності. Ось чому дослідники називають їх «портативними» (Перкінс, 1986). У закладах морської освіти мультидисциплінарне навчання всіляко підтримує та сприяє иій передачі. Міжпредметні вміння викликали суперечку серед викладачів: «чи існують міжфункиіональні вміння самі по собі, чи можна їх ідентифікувати та з'ясувати, чи можна скласти систему відліку, як у випадку заняття, чи цее загальний потенціал, який може виражатися за різних обставин?» (Паркон, 2006). Студенти можуть знаходити важливу інформацію в основних предметних галузях, але водночас вони не вчаться ефективно застосовувати свої знання у мисленні (Апплбі, Лангер, Мулліс, 1989). Тому стратегї моніторингу розуміння можуть бути спрямовані на читання матеріалів у будь-якій змістовній сфері.
\end{abstract}


Причинно-наслідкові зв'язки існують у міждисциплінарних дослідженнях. Мультидисциплінарне навчання - цее не просто шкільний досвід. Мультидисциплінарна програма передбачає, щуо одна й та сама навчальна тема розглядається в аспекті не однієї, а декількох дисииплін. Відповідно, таке навчання тісно пов'язане з тематичним та синергетичним викладанням (або «комбінованою взаємодією»). Заклади морської освіти бачать переваги мультидисииплінарного навчання та прагнуть інтегрувати його в свою освітню платформу. В статті досліджуються симбіотичні відносини між викладачем морської англійської мови та студентами з метою налагодження ефективного навчального середовища в умовах мультидисииплінарного навчання. Цей комплексний підхід до освіти потребує тісної співпраці викладачів для створення інтегрованого, розширеного навчання студентів різним дисциплінам. Здобувачі вищої освіти дізнаються більше, використовуючи знання морської англійської мови, щчоб проаналізувати те, чому їх навчили, записати все, чому їх навчили, і спілкуватися зі свойми одногрупниками, професорами та представниками морської індустрії.

Ключові слова: мультидисциплінарне навчання, міждисциплінарні вміння, морська англійська мова, симбіотичні відносини «викладач-студент».

\section{Introduction}

Education is a complex world with many styles, values, and philosophies. When choosing what is proper for us, it is essential to consider what system fits our learning methods. Multidisciplinary learning is a beautiful way to integrate our education into a complete unit rather than trying to draw connections between seemingly unrelated parts. The benefits of an interdisciplinary approach in education are abundant! Multidisciplinary learning is not our average school experience. The interdisciplinary curriculum is one in which a single topic comes from the viewpoint of more than one discipline. "The subject disciplines are put together through a central theme, issue, problem, process, topic, or experience" (Jacobs, 1989: 1-11). Accordingly, it is closely associated with thematic teaching and synergistic teaching (or "combined interaction"). Maritime Education and Training (MET) institutions see the advantages of multidisciplinary education and have gone above and beyond to integrate it into their education platform.

The interdisciplinary approach relies on people crossing disciplines to share knowledge, enhancing the scope and depth of learning. If someone need some multidisciplinary examples, think about a maritime transportation degree. Instead of just studying, for example, Navigation and Maritime Transportation Management separately, there are teachers from each department drawing on their specialty to provide a well-rounded understanding of the subject matter. Teachers can cross-pollinate their teachings to understand better how, i.e., Navigation and Maritime Transportation Management operate within this particular multitude of things belonging to the maritime industry.

\section{Multidisciplinary vs. Interdisciplinary in} Maritime Education and Training (MET)

The teachers' view is that a multidisciplinary approach has provided a creative way of linking subjects through a common theme to give students a meaningful, practical, and holistic context to learning that is very motivating. Students are enabled to prac- tice related skills in different subjects with the same context or problem. They can see that events do not happen in isolation, thus showing the relevance of science ideas and skills in a broader context. When successful, students find learning more comfortable because it is less disjointed and relevant. For one context, there are language demands associated. It is imperative in a multilingual work-class with many international students. The teachers have appreciated the opportunity to be more creative themselves and the opportunities to be versatile.

There are potentially significant advantages in multidisciplinary work, and teachers are still struggling to decide on a planning approach. For example, suppose a theme can link particular subjects such as "movements of the vessel". In that case, there are still subjects that will not fit logically within that theme because there are skills and concepts inadequately addressed. Interdisciplinary education is similar to multidisciplinary in the sense that it looks to combine knowledge from multiple disciplines. However, it emphasizes the importance of the process rather than the product of something. Interdisciplinary focuses on combining theories, methodologies, and perspectives from two or more disciplines; it connects a single theme or idea across disciplines.Therefore, should one subject be controlling, and others linked if, and only if, appropriate? If so, which one? How can a lack of balance be avoided? Ensuring progression and continuity of skills and knowledge is a significant challenge. "Even when teachers have identified a possible approach, many found that the current organizational practice of setting and timetabling make a whole-school cross-curricular process difficult" (Ofsted, 2006).

On the theoretical level of this analysis, Fogarty describes ten levels of curricular integration or multidisciplinary work:

"(1) Fragmented: separate and distinct disciplines.

(2) Connected: topics within a discipline are connected. 
(3) Nested: social, thinking, and content skills are targeted within a subject area.

(4) Sequenced: similar ideas are taught in concert, although subjects are separate.

(5) Shared: team planning and or teaching that involves two disciplines focuses on shared concepts, skills, or attitudes.

(6) Webbed: thematic teaching using a theme as a base for instruction in many disciplines.

(7) Threaded: thinking skills, social skills, multiple intelligences, and study skills threaded throughout the disciplines.

(8) Integrated: priorities that overlap multiple disciplines examined for common skills, concepts, and attitudes.

(9) Immersed: learner integrates by viewing all learning through one area of interest.

(10) Networked: The learner directs the integration process by selecting a network of experts and resources" (Fogarty, 1991).

For the maritime domain, the great match is this: Which one is appropriate for the maritime educational field? Fogarty's schema alerts us that adopting a cross-curricular approach requires scrutiny because the concept has various legitimate meanings. It does not have a single identity, so it cannot be a consensus among teachers over its definition, its implications for curriculum planning, or its significance for teaching and learning. Setting aside concerns over this report, supporters of multidisciplinary work agree that it is a means of establishing links across the humanities (history, geography, language, literature) or between the natural sciences and mathematics.

The author of this paper, in addressing multidisciplinary learning, confidently asserts that this approach offers a creative way to develop the students' knowledge, skills, and understanding while motivating them to learn through stimulating, related topics. Thus, crossing subject boundaries allows for investigations that engage students' imagination and encourages students to undertake an active inquiry, show initiative, and discuss and debate issues. The assimilation of this learning process considers the mixture of ideas and approaches related to the topic areas and life experiences to make education more relevant and meaningful for students. It is a way to support the transfer of learning environments and language skills from one situation to another, teach students to think and reason, and provide a more relevant curriculum to engage their interest. But to be successful with that it is vital to forget about: "I am your teacher of Maritime English! We have our lessons about activities described by using the Maritime Technical English terminology. I give you the definition and translation of them. Don't ask me particular explanations about e.g., the ship's movements. These are topics of Ship's Handling discipline! Yes, that is right, but you, the teacher of Maritime English should be prepared to help the student understand: use videos, or even a gesture to help his/her imagination in the very moment they have heard the new word. I agree with the fact that we are not "multi-purposes" teachers, but we need a little knowledge concentration about what we are teaching! [...] At our last memorable IMEC 25 in Istanbul we discussed marinisation of the Maritime English Teacher. That is the way!" (Chirea-Ungureanu, 2014: 29-30).

An interdisciplinary curriculum reflects the definition of interdisciplinarity and matches the main elements of interdisciplinarity. These elements include: " 1 -address to a complex problem or focus question not resolved by using a single disciplinary approach; 2 -draw on insights generated by disciplines, interdisciplines, or schools of thought, including non-disciplinary knowledge formations; 3 - integrating insights; 4 - producing an interdisciplinary understanding of the problem or question" (Reptko, 2008: 46-48). Supporters argue that by teaching the curriculum as an integrated whole, students' view of learning is more holistic ("rounded"). In contrast, if teachers emphasize the separation and discreteness of topics, it can establish artificial barriers in students' minds, and they may fail to make secure connections between knowledge components. Thus, the knowledge and skills of students in one area can be used and shared in other areas of their learning, thereby ending the subject barriers and matching parts of each subject into a blended whole.

\section{How might interdisciplinary learning affect} teachers and students altogether?

Learning has proven to positively impact teaching styles and relationships with both our colleagues and students. A curriculum with an interdisciplinary element encourages people to accept significant connections between these domains in designs that intrigue and motivate both teachers and students. Interdisciplinary, meaning "the guidance of thinking", gives a goal to study that runs beyond the evaluation and memorization of information related to a particular topic. It is a design element; it can push the teachers and the students toward more powerful thinking to make comparisons that bridge disciplines and encourage the application of knowledge. When we are engaging in this guidance, it can also positively affect us. Many teachers feel "alive" when using a fresh approach to old content. Many teachers feel "alive" when using a new method to old content. More than that, we can find a way to realize that we have been 
teaching facts for the sake of knowing facts, and, significantly, we must go back and redevelop our way of thinking and revise our lessons.

The facts described above can affect our interaction with our colleagues as well. When teachers must work together to develop effective units, they often feel a sense of collegiality and enthusiasm that is missing while working in isolation. Using interdisciplinary units in the curriculum can help teachers view their disciplines closely related, including teamwork and acknowledgment of their profession in general. The relationship between Marine Engineering and Nautical Sciences and Maritime English (ME) is complimentary. It allows teachers to attain students learning and development within a limited time frame through a creative approach. Maritime English and Marine Engineering, and Nautical Sciences can have a positive relationship. There are lessons to plan and structure to develop speaking and literacy skills while providing a real-life context for learning.

The national curriculum design for the English language reflects the importance of spoken language in students' training. The spoken language highlights the improvement of students' comprehension. Following this, teachers should help students in their attempt to achieve their goal: the students' competence in spoken language and listening skills. Students should be able to understand books and other reading and to be able to write their ideas. Teachers must help students to think clearly to themselves as well as to others. Students should also learn to understand and use the conventions for discussion and debate.

We cannot ignore that the concept of MELF (Maritime English as a Lingua Franca) at SEA with all its content has now been subtly and almost gradually incorporated in the syllabi, methodologies, and teaching goals of marine higher education institutions. This concept emphasizes the use of Maritime English (ME) as the communication language between multilingual people and non-native speakers of English as well. MELF at SEA aims to train students to use English and Maritime English to communicate in their professional environment, which may often be cross-cultural. In this context, the primary task of a ME teacher is to teach students the General English language. The target is the emphasis on clarity of communication instead of control over the nuances typical of native speakers. That helps learners to face the changes in today's multilingual work environment. Once the students hold the fundamental communication skills, they can get the local differences aspirated sounds, the "dark L", the suppression of $\mathrm{R}$, for example, by experience. The main concern of MELF at SEA, and by transference of ME teachers, is international intelligibility, which includes language and communication. The communication part needs interdisciplinary skills.

The traditional methods for teaching Maritime English (ME) communication skills are pretty odd. They must be supplemented with a different knowledge base and borrow heavily from Nautical Sciences and Marine Engineering. When the "marinisation" of teachers is complete, effective communication onboard vessels is the key to successful operations!

What are the required changes at this stage? For an ideal Maritime English teaching environment, there are a variety of ways to expose the learners. For example, simulation of different circumstances, the usage of multimedia techniques, or group activities. The latter should not be limited to holding group discussions or debates. The ME teacher should organize while evaluating the linguistic capabilities of each group. The study-cases can promote better learner participation. These exercises are delivered in small groups, and the activities should be closely linked with the lecture groups to avoid unnecessary repetition.

These activities perform at three levels. Level 1: auto-evaluation of the participants. Level 2: peer evaluation. Level 3: ME teacher evaluations and final analysis (the ME teacher should have digital competencies, computer knowledge for audio-video recording and screening). These activities promote fluency, impart confidence to the learner in effectively using Maritime English for communication. Workshops are helpful for weaker students to overcome psychological barriers. In all these activities, the ME teacher must display a willingness to do more than the assigned task. A motivated ME teacher can readily transform a student's life by affecting his/her career performance.

When students learn from a curriculum shaped by essential questions, they will be more likely to interact with the content. Instead of answering, "...BlaBla-Bla" when asked what they learned, students will retain higher levels of knowledge. Essential questions are like rational Velcro; they give students a "gluey" place to which their ideas adhere. Essential questions in an interdisciplinary unit focus on the inquiry. They help students to understand their curriculum by understanding what questions are directing their training and how.

e.g., Why motions of the ship have adverse effects on human performance relative to vessel design?

The choice of essential questions explains that they are inventive, but they also linked to the pragmatic conceptual commitment that frames what we will teach and what we will leave out. The best units for the curriculum draft the essential questions: they 
run readily with different topics to challenge the same question at certain times, from different perspectives to enrich their understanding of the unit's organizing center (Krajcik,1989: 55-56).

\begin{tabular}{|l|l|}
\hline Format & Example of an Organizing Centre \\
\hline Topic & Movements of ship \\
\hline Issue & Waves \\
\hline Theme & $\begin{array}{l}\text { Motion sickness with the Movements of ship } \\
\text { as examples }\end{array}$ \\
\hline Work & Task Performance decrements \\
\hline Problem & $\begin{array}{l}\text { What can we do to moderate the influence of } \\
\text { movements of ship on crew performance? }\end{array}$ \\
\hline
\end{tabular}

\subsection{What are the interdisciplinary units?}

To find an interdisciplinary unit, experts often begin by assessing the student's knowledge development that the unit will serve. Next, they identify the discipline fields that will be involved. Then, they propose draft titles and develop a concept wheel, a visual tool that helps determine the unit's organizing center and essential questions. Education focuses on skill development in high schools, such as the four language skills: listening, speaking, reading, writing, basic fundamental sciences, and thinking skills apply to content. Once students leave high school, the focus commonly shifts from teaching skills to content coverage. This activity is still used in many schools in Romania while integrating the curriculum content, and the processes of thinking and teaching skills are missing. The polarity between those who promote interdisciplinary learning and those who fear replacing discipline-based knowledge is present. These limited multidisciplinary approaches are missing in higher education institutions as well.

\subsection{How do we find connections between the disciplines that work?}

To agree with a forced connection, that is a contradiction in terms and also a weak design. A link based on a mundane organizing center or theme can be exciting for students, but we do not necessarily get any building. Over the examples of interdisciplinary curriculum design, we have seen coordinated units in parallel disciplines. We should consider two teachers teaching separate units on ME/Movements of ship and Ship's Handling or Ships Hydromechanics. They might decide to give these units simultaneously in the academic year. The usage of parallel design of disciplines permits students to learn about a topic from different perspectives of multiple disciplines simultaneously. Still, it does not use organizing centers and essential questions to make those disciplines work together genuinely interdisciplinary manner. The excellent design for the interdisciplinary unit uses organizing centers and essential questions as a con- ceptual microscope that verifies each discipline base in-depth and integrity while at the same time exposing relationships among the disciplines. Finding these relationships stimulates students to think at a higher cognitive level.

\subsection{How can teachers evaluate the students in} an interdisciplinary unit?

Evaluation is a common concern of interdisciplinary teams. There might be confusion about who should grade what. Often, the student will produce a project or theme-work, and the team assigns the writing and grammar grade to the ME teacher. In contrast, whoever's teaching the other discipline represented in the project or theme-work is given the rate for content and analysis. But, using this kind of grading, a wrong message to students can be sent by default: "You don't have to be good in grammar and writing skills in science; that only matters in language arts and your science grade rests on the content and analysis" (Jacobs, 1996: 56).

If we are teaching an interdisciplinary unit, the last thing we want to do is segregate the disciplines all over again by how we grade! In considering assessments for our unit, the process is just as important as the product. We can evaluate a student's development, but we can also assess their skills while analyzing their work styles. Assessing group work is especially important. We may want to include a "process" or "ability to cooperate and work in groups" grade in our assessments. Keep in mind that students can assess each other and themselves as part of the overall assessment plan for the unit. Examinations can take all forms, from continuum evaluation tests to programmed assessments. Imagine the students' reviews as making a movie, not a snapshot: a continuum, multilevel method that runs continuously throughout a student's complete study (Jacobs, 1989: 55-56).

\section{Conclusions}

The more heavily interrelated the skills and information of students become the more structured students' learning is. That allows for the metacognitive transfer of knowledge from one situation to the next and supports students' progressive growth. So instead of thinking about how different our area of expertise is from other disciplines, we should consider how we can start a conversation with our colleagues about what subjects we have in common.

The great dilemma: "What Approach To The Core Subjects: "Discrete or Cross-Curricular?" (Mason, 2015). There are benefits and traps to both strategies. There is a considerable benefit to students having a vast and enriching learning experience that draws together subject knowledge. Although cross-curricular teaching can sometimes sacrifice vital learning 
in fundamental subject areas if not planned for sufficiently. Overall, the cross-curricular education prioritizes more as long as the planning and implementation matters.

Teachers have testified the benefits of thinking skills in multidisciplinary collaboration and how this aids students' transferability of knowledge and skills. We observed that the thinking skills activities helped the students to learn by providing them with a focus for collaboration. However, it is worth seeing that, for a small minority, their perception of "collaboration" was not always perfect. The highest benefits allotted time to "thinking skills" and engaged explicitly in a collaborative setting. This inquiry has opened numerous possibilities to improve our thinking skills practice, particularly in the ongoing design and modification of the curriculum.

Our analysis provided evidence that cross-curricular work applying thinking skills benefit students of all accomplishment levels and in different ways. The approach has encouraged students to see whereby thinking skills, like ordering and organizing, can approach a topic from a different angle. It also seems to help them see the transferability of such skills beyond their learning in various subjects. This aspect could lead to a greater awareness of themselves as learners and whereby they learn.

Cross-curricular approaches, intercultural studies, the learning of languages following content-based teaching, materials improvement for the new curricula, and methods create current research areas worldwide. The challenging new ideas aspire to add valuable insights into the relevant issues and promote ideas and practices. Many practitioners act toward implementing interdisciplinary approaches, which seem to take various forms according to the educational and cultural context. The results of such applications should be of interest to all stakeholders, national educational policy, researchers, and teachers alike. The need for educational policy designers to evaluate educational innovations regarding the impact of such approaches on learners' progress is here, including the necessity of teachers for more concrete teaching applications.

\section{BIBLIOGRAPHY}

1. Perkins, D. Knowledge as a Design. Routledge, 1986.

2. Parcon, P. Develop Your Team Building Skills. Lotus Press, 2006.

3. Applebee, Langer, Mullis. Crossroads in American education. Princeton, N.J. : Educational Testing Service, 1989.

4. Jacobs, H. H. The Growing Need for Interdisciplinary Curriculum Content / H. H. Jacobs (ed.). Interdisciplinary Curriculum: Design and Implementation. Alexandria, Va. : Association for Supervision and Curriculum Development, 1989. P. 1-11.

5. Ofsted The Logical Chain: Continuing Professional Development in Effective Schools. Document reference number HMI 2639. London : Office for Standards in Education, 2006. URL: www.ofsted.gov.uk.

6. Fogarty, R. How to Integrate the Curricula: The Mindful School. Palatine, IL : Skylight Publishing, Inc, 1991. URL: http://www.ascd.org/ASCD/pdf/journals/ed_lead/el_199110_fogarty.pdf.

7. Chirea-Ungureanu, C. Why do some people say the English Language is hard to learn, and Maritime English is hard to master? IMEC 26, Proceedings, Terchelling, The Netherlands, 7-10 July 2014. P. 29-30.

8. Reptko, A. Interdisciplinary Research: Process and Theory. Kindle Edition, 2008. P. 46-48. URL: https://www.semanticscholar.org/paper/Interdisciplinary-curriculum designRepko/eabd7b66307c495b2b8c3e0f6472d984fb $81 \mathrm{bc} 05$.

9. Krajcik, J. Characteristics of Driving Questions. URL: http://www-personal.umich.edu/ krajcik/DQ.html).

10. Jacobs, H. H. The Interdisciplinary Concept Model: A Step-by-Step Approach for Developing Integrated Units of Study. Interdisciplinary Curriculum: Design and Implementation. Alexandria, Va. : Association for Supervision and Curriculum Development, 1989. P. 55-56.

11. Jacobs, H. H. Breaking Ranks: Changing an American institution. Reston, Va. : National Association of Secondary School Principals, 1996. P. 56.

12. Mason, R. Key Concepts of Cross-Curricular Teaching. URL: https://prezi.com/ev1rbae-1nix/discrete-or-crosscurricula/.

\section{REFERENCES}

1. Perkins, D. Knowledge as a Design. Routledge, 1986.

2. Parcon, P. Develop Your Team Building Skills. Lotus Press, 2006.

3. Applebee, Langer, Mullis. Crossroads in American education. Princeton, N.J. : Educational Testing Service, 1989.

4. Jacobs, H. H. The Growing Need for Interdisciplinary Curriculum Content. Interdisciplinary Curriculum: Design and Implementation. Alexandria, Va. : Association for Supervision and Curriculum Development, 1989. P. 1-11.

5. Ofsted. The Logical Chain: Continuing Professional Development in Effective Schools. Document reference number HMI 2639. London : Office for Standards in Education, 2006. URL: www.ofsted.gov.uk.

6. Fogarty, R. How to Integrate the Curricula: The Mindful School. Palatine, IL : Skylight Publishing, Inc, 1991. URL: http://www.ascd.org/ASCD/pdf/journals/ed_lead/el_199110_fogarty.pdf. 
7. Chirea-Ungureanu, C. Why do some people say the English Language is hard to learn, and Maritime English is hard to master? IMEC 26, Proceedings, Terchelling, The Netherlands, 7-10 July 2014. P. 29-30.

8. Reptko, A. Interdisciplinary Research: Process and Theory. Kindle Edition, 2008. P. 46-48. URL: https://www.semanticscholar.org/paper/Interdisciplinary-curriculum designRepko/eabd7b66307c495b2b8c3e0f6472d984fb $81 \mathrm{bc} 05$.

9. Krajcik, J. Characteristics of Driving Questions. URL: http://www-personal.umich.edu/ krajcik/DQ.html).

10. Jacobs, H. H. The Interdisciplinary Concept Model: A Step-by-Step Approach for Developing Integrated Units of Study. Interdisciplinary Curriculum: Design and Implementation. Alexandria, Va. : Association for Supervision and Curriculum Development, 1989. P. 55-56.

11. Jacobs, H. H. Breaking Ranks: Changing an American institution. Reston, Va. : National Association of Secondary School Principals, 1996. P. 56.

12. Mason, R. Key Concepts of Cross-Curricular Teaching. URL: https://prezi.com/ev1rbae-1nix/discrete-or-crosscurricula/. 